\title{
Is There any Possible Role of Neurotrophin 3 in the Pathogenesis of Antrochoanal Polyp?
}

\author{
Antrokoanal Polipin Patojenezinde Neurotrophin 3'ün Rolü Var mı?
}

\author{
Cengiz OZCAN $\odot$, Onur ISMI $\odot$, Tuba KARA $\odot$, Gurbuz POLAT $\odot$, Osman ERDOGAN $\odot$, \\ Senay BALCI FIDANCI $\odot$, Yusuf VAYISOGLU $\odot$, Kemal GORUR $\odot$
}

Ethics Committee Approval: This study was approved by the Mersin University, Clinical Studies Ethic Committee, 8 October 2015, 2015/314.

Conflict of interest: The authors declare that they have no conflict of interest.

Funding: None.

Informed Consent: Informed consent was taken from the patients enrolled in this study.
Cite as: Ozcan C, Ismi O, Kara T, et al. Is there any possible role of neurotrophin 3 in the pathogenesis of antrochoanal polyp?. Medeniyet Med J. 2020;35:40-6.

\begin{abstract}
Objective: Antrochoanal polyp (ACP) is a benign soft tissue lesion arising from the inner wall of the maxillary sinus that extends into the nasal cavity and choana. Although it was first explained by Killian in 1906, the underlying pathogenesis has not been yet fully understood. Neurotrophins have been demonstrated to have a possible role in the pathogenesis of allergic rhinitis, idiopathic rhinitis and nasal polyps. To date any study has not investigated the function of neuronal inflammation and neurotrophins in the development of ACP. The objective of this study was to investigate the possible effect of neurotrophin-3 (NT-3) in ACP pathogenesis.

Method: Twenty adult patients with ACP who underwent endoscopic sinus surgery in our department were included in the study group. The control group included 15 patients with concha bullosa of middle concha who underwent lateral excisional surgery. Nasal tissue NT-3 staining scores were evaluated using immunohistochemical methods. Blood NT-3 levels of both groups were evaluated by enzyme-linked immunosorbent assay (ELISA).

Results: There were no statistically significant differences between these two groups regarding tissue NT-3 staining scores $(p=0.843)$ and blood NT-3 levels $(p=0.463)$. In addition, no statistically significant correlation has been observed between tissue NT-3 staining scores and blood NT-3 levels in both ACP $(p=0.578)$ and control $(p=0.359)$ group patients.

Conclusion: NT-3-related neuronal inflammation does not seem to have any role in ACP pathogenesis.
\end{abstract}

Keywords: Antrochoanal polyp, nasal polyp, neuronal inflammation, neurotrophin, neurotrophin 3, pathogenesis

\section{öz}

Amaç: Antrokoanal polip (AP), maksiller sinüs iç duvarından kaynaklanan, nazal kavite ve koanaya uzanan benign yumuşak doku lezyonudur. Ilk kez 1906'da Killian tarafindan açıklanmasına rağmen, altta yatan patogenezi halen tam olarak anlașılamamıștır. Nörotropinlerin alerjik rinit, idiyopatik rinit ve nazal polip patogenezinde rolü olabileceği gösterilmiştir. Bugüne kadar nöronal inflamasyon ve nörotropinlerin AP oluşumundaki fonksiyonunu araştıran çalıșma bulunmamaktadır. Bu çalışmanın amacı, Nörotropin 3 (NT-3)'ün AP patogenezinde olası etkisini araştırmaktır. Yöntem: Calıșmaya kliniğimizde endoskopik sinüs cerrahisi yapılan AP'li 20 erişkin hasta alınmıştır. Kontrol grubu, lateral eksizyon yapılan 15 orta konka büllozalı hastayı içermektedir. Nazal dokuda NT-3 boyanma skorları immünohistokimya ile değerlendirilmiştir. Her iki grubun kan NT-3 seviyeleri Enzyme linked immunosorbent assay (ELISA) ile değerlendirilmiştir.

Bulgular: Iki grup arasında doku NT-3 boyanma skorları $(p=0,843)$ ve kan $N T-3$ seviyeleri $(p=0,463)$ bakımından anlamlı fark yoktur. Ek olarak doku NT-3 boyanma skorları ile kan NT-3 seviyeleri arasında hem AP $(p=0,578)$ hem de kontrol $(p=0,359)$ grubunda istatistiksel olarak anlamlı korelasyon yoktu.

Sonuç: NT-3 bağımlı nöronal enflamasyonun, AP patogenezinde rol oynamadığı düşünülmüştür.

Anahtar kelimeler: Antrokoanal polip, nazal polip, nöronal enflamasyon, nörotropin, nörotropin 3, patogenez
Received: 17 December 2019

Accepted: 7 January 2020

Online First: 28 February 2020

Corresponding Author:

O. Ismi

ORCID: 0000-0001-5061-8907

Mersin University

Department of Otorhinolaryngology,

Mersin, Turkey

dronurismi@gmail.com

C. Ozcan

ORCID: 0000-0001-7649-9782

O. Erdogan

ORCID: 0000-0001-9384-7881

Y. Vayisoglu

ORCID: 0000-0002-7132-1317

K. Gorur

ORCID: 0000-0002-2147-4673

Mersin University,

Department of Otorhinolaryngology,

Mersin, Turkey

T. Kara

ORCID: 0000-0002-7338-213X Mersin University,

Department of Pathology, Mersin, Turkey

G. Polat

ORCID: 0000-0003-3589-1299

S. Balci Fidanci

ORCID: 0000-0002-7498-604X

Mersin University,

Department of Biochemistry, Mersin, Turkey 


\section{INTRODUCTION}

Antrochoanal polyp (ACP) is a polypoid mass arising from the maxillary sinus, extending into the nasal cavity and choana through the natural or accessory ostium. It has two main components: a cystic, intramaxillary part and a solid polypoid part $^{1}$. They are infrequent lesions when compared to common inflammatory nasal polyps (NPs). They comprise $3-6 \%$ of all NPs, but the incidence can be as high as $22.3 \%^{2,3}$. The underlying pathogenesis of ACP development has not been fully understood, yet. Chronic maxillary rhinosinusitis, allergic rhinitis (AR), tooth trauma, microvascular disorder and lymphatic obstruction have all been suggested as causative factors for $\mathrm{ACP}^{1,2,4,5}$. Investigation of ultrastructural morphology of ACPs with transmission electron microscopy demonstrated that few eosinophils and greater number of other inflammatory cells with normal surface epithelium and basement membrane have suggested chronic inflammation rather than allergy in the pathogenesis of $\mathrm{ACP}^{1}$.

The primary treatment of ACP is surgery. Initially, Caldwell-Luc operation together with simple avulsion was used, but today endoscopic sinus surgery is the most preferred surgical technique ${ }^{4,6}$. Recently, transnasal prelacrimal recess approach has been used for recurrent cases ${ }^{7}$.

Neurogenic inflammation refers to a cascade of neuroimmune interactions which results in inflammatory cell infiltration in the airway. Stimulated nasal nociceptive type $C$ nerve fibers have the ability to initiate secretion of tachykinins including substance $P(S P)$, calcium gene-related peptide (CGRP) and neurokinin A. These proteins initiate plasma leakage, glandular secretion and the release of inflammatory cells that induce the airway inflammation ${ }^{8}$. Neurotrophins consist of nervegrowing factors which were firstly described as neurotrophic proteins that take part in development of neurons, formation of synapse and neuronal plasticity 9 . Nerve growth factor (NGF) is the firstly described protein of neurotrophin family. Brain- derived neurotrophic factor (BDNF), neurotrophin 3 (NT-3) and NT 4/5 also exist. These neuropeptides have been also demonstrated to trigger neurogenic inflammation in the nasal mucosa by stimulating the nociceptive type $\mathrm{C}$ fibers $^{8}$.

Neurotrophins were also demonstrated to have role in allergic rhinitis (AR) and pathogenesis of idiopathic rhinitis $^{7-10}$. In addition, there were two articles about the function of neurotrophins in chronic rhinosinusitis and pathogenesis of NP ${ }^{11,12}$. Recently, NT-3 has been shown to have a local effect on the development of non-allergic $\mathrm{NP}^{13}$. Although the main source of neurotrophins are eosinophils in the nasal mucosa, epithelial cells are another important source ${ }^{9}$.

Limited number of articles have focused on the molecular mechanisms involving in the pathogenesis of $\mathrm{ACP}^{14-18}$ and the possible role of neuronal inflammation in ACP development has not been studied yet. The neurotrophins other than NT-3 were studied largely in the nasal airway inflammation $^{8-12}$, therefore we aimed to evaluate the possible role of NT-3 in patients with ACP by analyzing tissue NT-3 levels using immunohistochemical and serum NT-3 levels with enzymelinked immunosorbent assay (ELISA).

\section{MATERIALS and METHODS}

Approval of ethics committee was acquired for our study with a decision number of 2015/314. Written informed consent was obtained from all patients that participated in the study.

Power analysis of the study was performed according to the results of former studies assessing the relationship between NP pathogenesis and NT-3. Accordingly, the minimum sample size was 12 for each group. The study group consisted of 20 patients with ACP who underwent endoscopic sinus surgery and control group consisted of 15 
patients with concha bullosa who underwent partial excision in our Otorhinolaryngology Department. Main complaint of all patients was nasal obstruction. The diagnosis of patients with ACP or concha bullosa was made based on physical examination, anterior rhinoscopy, intraoral examination, nasal endoscopy using rigid Hopkins telescopes of $0^{\circ}$ and $30^{\circ} 4 \mathrm{~mm}$. nasal endoscopes (Karl Storz ${ }^{\circledR}$-Tuttlingen-Germany) and maxillofacial computed tomography results. Skin prick or blood specific IgE (sIgE) tests were performed in all patients. Sixteen allergens were used for skin Prick test panel and 35 allergens for blood slgE panel. Patients with positive skin test or sIgE levels were excluded from the study so as to rule out the result of allergy on the study outcomes. Besides AR, patients with allergic fungal sinusitis, neurological disorders including multiple sclerosis, Parkinsonism and epilepsy were not also included in the study.

\section{Immunohistochemistry of tissue specimens}

All ACP and concha bullosa specimens were obtained during surgical procedures performed under general anesthesia. Specimens from the sinus and nasal parts of the ACP in the study and concha bullosa in the control group were obtained using cutting and Blackesley forceps. The ACP and middle turbinate mucosa specimens were fixed in $10 \%$ formalin solution. The sections of specimens were immunostained for NT-3 (Santa Cruz ${ }^{\circledR}$, Texas, USA, dilution 1:200) according to the directions of the manufacturer ${ }^{19}$. The staining of NT-3 was observed in interstitial matrix and the cytoplasm of the inflammatory cells. Concisely, the intensity of immunostaining was analyzed. The staining intensity of NT-3 was scored semi-quantitatively in five groups: absent $(0)$, weak $(+1)$, moderate $(+2)$, strong $(+3)$, and very strong $(+4)^{13,20}$. The pathologist examining the sections was blinded to the study during immunohistochemical analysis. Weak (+1) and strong (+3) staining intensities of the nasal mucosa samples are demonstrated in Figures 1 and 2, respectively.

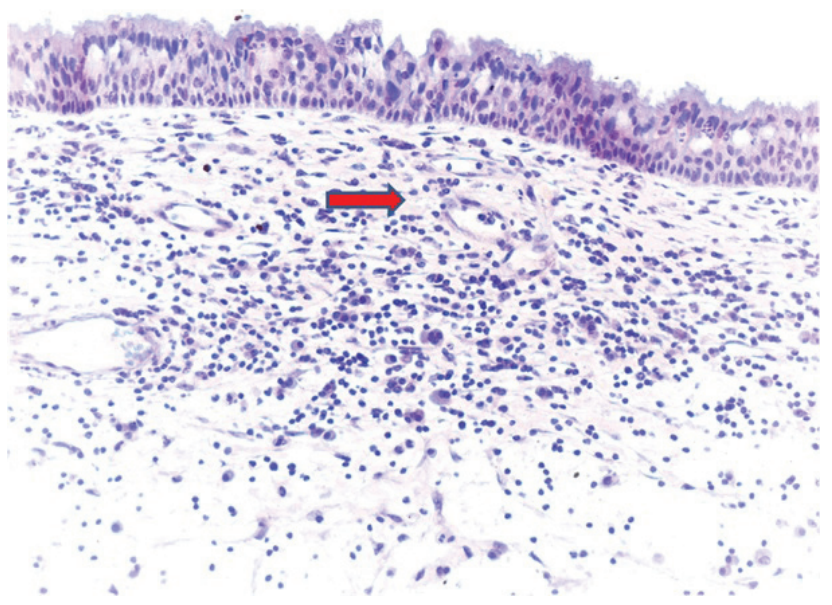

Figure 1. Weak staining $(+1)$ with NT-3 in the interstitial matrix (arrow) of the patient's nasal mucosa (x200, NT-3).

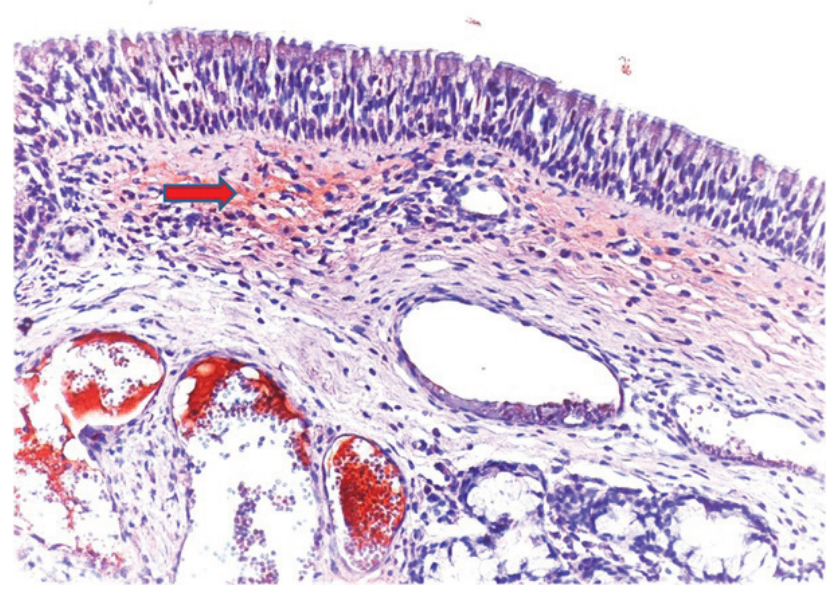

Figure 2. Strong staining $(+3)$ with NT-3 in the interstitial matrix (arrow) of the patient's nasal mucosa (x200, NT-3).

\section{ELISA for Serum Samples}

Blood samples from all patients were drawn by venipuncture into plain tubes, and instantly centrifuged at $4000 \mathrm{~g}$ for 10 minutes at $4^{\circ} \mathrm{C}$. The serum samples were stored at $-20^{\circ} \mathrm{C}$ until the assay. NT-3 levels were determined in the DSX'⿳亠口冋 Four-Plate Automated ELISA Processing System MicroELISA (Dynex Tecnologies, Virginia, USA), using the "Human NT-3 ELISA kit" (YH Biosearch Laboratory, Shanghai, China) according to the manufacturer's directions. The results are presented as $\mathrm{pg} / \mathrm{ml}$.

\section{Statistical Analysis}

Statistical assessment was performed using SPSS 
version 23.0 (IBM SPSS Inc. USA-2015). Chisquare test was used to compare the distribution of the two groups according to the gender. Student's t-test was used to evaluate age disparity between two groups. Data were evaluated for normal distribution by using Shapiro-Wilk test. The Mann-Whitney $U$ test was used to compare serum NT-3 levels between groups. Tissue NT-3 staining scores were also compared by using the Mann-Whitney $U$ test. Correlation coefficient was used to assess the association between staining scores and serum NT-3 levels in both groups. P value of $<0.05$ was accepted as statistically significant.

\section{RESULTS}

There were 13 male patients in the ACP and 9 male patients in the control group. The mean age of ACP group was $36.95 \pm 11.6$; while the mean age of control group was $37.93 \pm 8.17$ years. There were no statistically significant intergroup differences regarding gender $(p=0.762)$ and age $(p=0.781)$ of the patients.

Serum NT-3 levels and tissue NT-3 staining scores of each patient are given in (Table 1).

Table 1. Comparison of serum Neurotrophin 3 levels and tissue Neurotrophin staining scores of the patients were presented.

\begin{tabular}{|c|c|c|c|}
\hline & $\begin{array}{l}\text { Acp group } \\
(n=20)\end{array}$ & $\begin{array}{l}\text { Control group } \\
(n=15)\end{array}$ & $\begin{array}{l}P \\
\text { value }\end{array}$ \\
\hline $\begin{array}{l}\text { Serum NT-3 } \\
\text { levels }(p g / m l) \\
(\text { Mean } \pm S D, \text { min-max })\end{array}$ & $\begin{array}{l}605.9 \pm 238.8 \\
66-868.1\end{array}$ & $\begin{array}{l}628.9 \pm 244.9 \\
88-980\end{array}$ & 0.463 \\
\hline $\begin{array}{l}\text { Tissue Staining scores } \\
(\text { Mean } \pm S D \text {, min-max })\end{array}$ & $\begin{array}{l}0.85 \pm 0.93 \\
0-(+3)\end{array}$ & $\begin{array}{l}0.8 \pm 0.9 \\
0-(+3)\end{array}$ & 0.843 \\
\hline
\end{tabular}

NT-3: Neurotrophin 3, ACP: Antrochoanal polyp, SD: Standard deviation, min: Minimum value, max: Maximum value

Mean tissue staining scores of ACP and control groups were $0.85 \pm 0.93$ and $0.8 \pm 0.9$, respectively. There wasn't any statistically significant difference between these two groups concerning tis- sue NT-3 staining scores ( $p=0.843)$. Comparison of staining scores between two groups are presented in Figure 3.

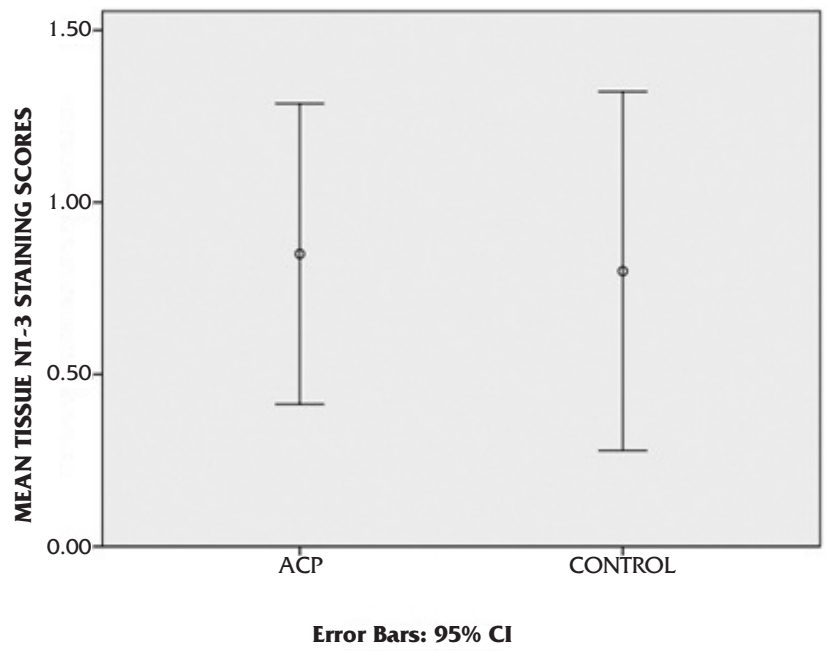

Figure 3. Comparison of tissue Neurotrophin 3 staining scores between two groups has been demonstrated. (NT-3: Neurotrophin 3, ACP: antrochoanal polyp).

Mean serum NT-3 levels of ACP and concha bullosa groups were $605.9 \pm 238.8 \mathrm{pg} / \mathrm{ml}$ and $628.9 \pm 244.9 \mathrm{pg} / \mathrm{ml}$, respectively. There wasn't any statistically significant difference between these two groups concerning blood NT-3 levels $(p=0.463)$. Comparison of serum NT-3 levels between two groups is demonstrated in Figure 4.

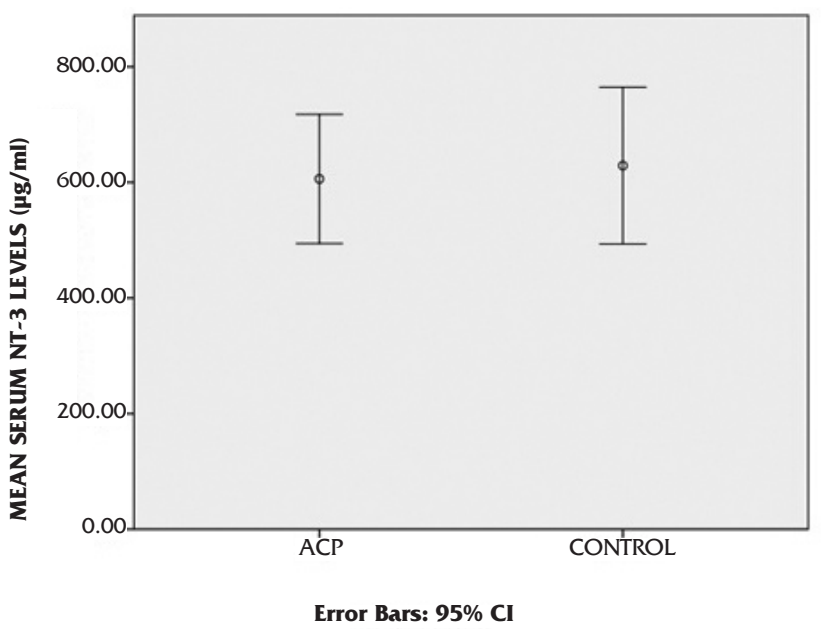

Figure 4. Comparison of serum Neurotrophin 3 levels between groups was presented. (NT-3: Neurotrophin 3, ACP: antrochoanal polyp). 
When Pearson correlation coefficient was calculated, any statistically significant correlations were not observed between tissue NT-3 staining scores and blood NT-3 levels in both ACP ( $p=0.578)$ and control $(p=0.359)$ groups.

\section{DISCUSSION}

We did not detect any statistically significant differences concerning blood NT-3 levels and nasal tissue NT-3 staining scores between ACP and control groups.

ACP is the polypoid lesion of middle meatus originating from the maxillary antrum and extending into the nasal cavity and choana ${ }^{1}$. Although, it was firstly explained by Prof. Killian in $1906^{21}$, the underlying pathogenesis has not yet been fully understood. According to Mills ${ }^{5}$, ACP arises from large acinous mucous glands whose ducts were blocked during the healing process of maxillary sinus infection. Rupture of these glands forms one big intramaxillary cyst that pushes the sinus mucosa away from bony part of the maxillary sinus wall. On the other hand, Berg et al. ${ }^{22}$ suggested that intramaxillary cystic part of the ACPs originates from intramural cysts that can be frequently found in the healthy population. Min et al. ${ }^{23}$ claimed that the origin of ACP was edematous respiratory epithelium rather than glandular structures due to the paucity of submucosal glands in the histological examination of ACP. Infection or allergy related chronic inflammation occluding the antral ostium has been also speculated. Trapped air during obstruction of maxillary sinus ostium increases the tension inside the antrum and forces the preexisting antral cyst to herniate outside by the principle of Bernoulli phenomenon giving rise to ACP development ${ }^{24}$. When the ACP completely fills the nasopharynx, it is also speculated that it prevents formation of enough negative intranasal pressure in the contralateral side for development of contralateral ACP, so bilateral ACP cases are very rarely seen ${ }^{25}$. Lymphatic vessel obstruction rather than glandular obstruction has been also proposed as a causative factor for the development of $\mathrm{ACP}^{2}$. Regarding molecular mechanisms, protease and proactivator-dependent proliferation ${ }^{17}$, urokinase type plasminogen activator ${ }^{18}$, arachidonic acid metabolites ${ }^{16}$, inducible nitric oxide ${ }^{14}$ and human papilloma virus ${ }^{16}$ infection ${ }^{26,27}$ have been assumed to participate in the pathogenesis of ACP.

Inflammatory NP and ACP differ greatly. Nasal polyps are mostly bilateral, whereas bilateral ACPs are very rare. Ethmoid sinus is the most common paranasal sinus that NPs originate from, whereas ACPs originate from maxillary sinus mucosa ${ }^{24-27}$. Regarding cytokine profiles, eosinophil-related IL-5 is much more common in inflammatory NP, on the under hand proinflammatory cytokine IL-6 is more frequently seen in $A C P^{1}$. There are also clear-cut histological differences between ACP and NP. ACP contains smaller amount of inflammatory infiltrate and significantly lesser amount of eosinophilic infiltration. ACP also contains lesser number of submucosal glands when compared to $\mathrm{NP}^{23,28}$. Ultrastructural investigation of these polyps with electron microscopy confirmed the presence of smaller amounts of inflammatory cell and eosinophilic infiltration in $\mathrm{ACP}^{1}$. Surface epithelium and basement membrane of nasal mucosa retain their normal morphology in the ACP, however a higher number of goblet cells are found in NP. These ultrastructural findings suggest that chronic inflammation is more important than allergy in the pathogenesis of $\mathrm{ACP}^{1}$.

Neurotrophins are similar proteins as regards to their receptor affinities and their physiological functions. They were firstly described by their significant functions in the development and differentiation of nervous system. They also have an active role in inflammatory reactions of allergic diseases such as allergic rhinitis and asthma9,29. The sources of neurotrophins in the nasal mucosa are epithelial and inflammatory cells (eosinophils, neutrophils and mast cells) ${ }^{9,29}$. Activated eosinophils are the main inflammatory cells that can 
produce, store and release neurotrophins during cascade reactions of airway inflammation ${ }^{30,31}$. Neurotrophins can activate the nasal nociceptive type C fibers and stimulate release of SP, CGRP and neurokinin $\mathrm{A}$ in the inflammatory reaction in the airway. These tachykinins contribute to the inflammatory events by degranulation of mast cells, vasodilatation, secretion of mucus, cytokine synthesis and eosinophil chemotaxis ${ }^{8}$. Additionally, neurotrophins can activate eosinophils to secrete IL-4, inhibit eosinophil apoptosis, induce proinflammatory cytokine release from lymphocytes and regulate survival of mast cells ${ }^{9,29}$.

The roles of neurotrophins in the pathogenesis of NPs have been also investigated. It has been shown that NP epithelial cells express higher amounts of BDNF compared to turbinate cells and proinflammatory cytokines increase the BDNF expression in cell cultures ${ }^{11}$. On the other hand, Coffey et al. ${ }^{12}$ found lower tissue BDNF and higher tissue NGF concentration in the NP group patients. The serum levels of the neurotrophins were not evaluated in patients with NP in mentioned studies. Recently, we have demonstrated that NT-3 may have local effect in NP pathogenesis without joining the systemic circulation ${ }^{13}$. Most NPs demonstrate eosinophilic inflammation ${ }^{12}$. In the findings of these studies ${ }^{11-13}$, the interaction between neurotrophins and activated eosinophils $\mathrm{s}^{30,31}$ might be the cause of higher amounts of neurotrophins in the NP tissue. We concluded that paucity of eosinophilic inflammation in the ACP tissue is the most probable cause of similar serum NT-3 levels and tissue NT-3 staining between ACP and control group patients in our study.

\section{CONCLUSION}

NT-3-related neuronal inflammation does not seem to have an important role in the pathogenesis of ACP. Larger-scale studies investigating other neurotrophins may reveal the importance of neuronal inflammation in the pathogenesis of ACP.

\section{REFERENCES}

1. Ozcan C, Zeren H, Talas DU, Küçükoğlu M, Görür K. Antrochoanal polyp: a transmission electron and light microscopic study. Eur Arch Otorhinolaryngol. 2005;262:5560. [CrossRef]

2. Mostafa HS, Fawzy TO, Jabri WR, Ayad E. Lymphatic obstruction: a novel etiologic factor in the formation of antrochoanal polyps. Ann Otol Rhinol Laryngol. 2014;123:381-6. [CrossRef]

3. Cook PR, Davis WE, McDonald R, McKinsey JP. Antrochoanal polyposis: a review of 33 cases. Ear Nose Throat J. 1993;72:401-2. [CrossRef]

4. Deka RC. Antrochoanal polyp: Its pathogenesis origin and management by functional endonasal endoscopic surgery. Indian J Otolaryngol Head Neck Surg. 1999;51:33-5. [CrossRef]

5. Mills CP. Secretory cysts of the maxillary antrum and their relation to the development of antrochoanal polypi. J Laryngol Otol. 1959;73:324-34. [CrossRef]

6. Ozcan C, Unal M, Görür K, Pata YS. A review of antrochoanal polyps in 14 cases. Kulak Burun Bogaz Ihtis Derg. 2002;9:188-92.

7. Comoglu S, Celik M, Enver N, Sen C, Polat B, Deger K. Transnasal Prelacrimal Recess Approach for Recurrent Antrachoanal Polyp. J Craniofac Surg. 2016;27:1025-7. [CrossRef]

8. Ismi O, Ozcan C, Karabacak T, et al. Local Effect of Neurotrophin-3 in Neuronal Inflammation of Allergic Rhinitis: Preliminary Report. Balkan Med J. 2015;32:364-70. [CrossRef]

9. Manti S, Brown P, Perez MK, Piedimonte G. The Role of Neurotrophins in Inflammation and Allergy. Vitam Horm. 2017;104:313-341. [CrossRef]

10. Gelincik A, Aydın F, Ozerman B, et al. Enhanced nerve growth factor expression by mast cells does not differ significantly between idiopathic and allergic rhinitis. Ann Allergy Asthma Immunol. 2012;108:396-401. [CrossRef]

11. Jornot L, Grouzmann E, Lacroix JS, Rochat T. BDNF and DPP-IV in polyps and middle turbinates epithelial cells. Rhinology. 2007;45:129-33.

12. Coffey CS, Mulligan RM, Schlosser RJ. Mucosal expression of nerve growth factor and brain-derived neurotrophic factor in chronic rhinosinusitis. Am J Rhinol Allergy. 2009;23:571-4. [CrossRef]

13. Ismi O, Kara T, Polat G, Bobusoglu O, Vayısoglu Y, Gorur $\mathrm{K}$, Ozcan C. Is there any effect of neurotrophin-3 on the pathogenesis of non-allergic nasal polyps? J Laryngol Otol. 2018;132:724-728. [CrossRef]

14. Ozcan C, Apa DD, Pata YS, Görür K, Akbaş Y. Expression of inducible nitric oxide synthase in antrochoanal polyps. Int J Pediatr Otorhinolaryngol. 2003;67(4):383-8. [CrossRef]

15. Rudack C, Stoll W, Bachert C. Cytokines in nasal polyposis, acute and chronic sinusitis. Am J Rhinol. 1998;12:383-8. [CrossRef]

16. Jang YJ, Rhee CK, Oh CH, Ryoo HG, Kim HG, Ha M. Arachidonic acid metabolites in antrochoanal polyp and nasal polyp associated with chronic paranasal sinusitis. Acta Otolaryngol. 2000;120:531-4. [CrossRef]

17. Kosugi T, Morimitsu T, Matsuo O, Mihara H. A proteaseantiprotease system in antrochoanal polyp. I. Evidence for the existence of proactivator. Arch Otorhinolaryngol. 1979;225:97-102. [CrossRef] 
18. Sunagawa $M$, Kinjoh K, Nakamura $M$, Kosugi T. Urokinase-type plasminogen activator and plasminogen activator inhibitor antigen in tissue extracts of paranasal sinus mucous membranes affected by chronic sinusitis and antrochoanal polyps. Eur Arch Otorhinolaryngol. 1999;256:237-41. [CrossRef]

19. Barcena de Arellano ML, Wagner MF, et al. Neurotrophin expression is not affected in uteri of women with adenomyosis. J Mol Neurosci. 2012;47:495-504. [CrossRef]

20. Raap U, Fokkens W, Bruder M, Hoogsteden H, Kapp A, Braunstahl GJ. Modulation of neurotrophin and neurotrophin receptor expression in nasal mucosa after nasal allergen provocation in allergic rhinitis. Allergy. 2008;63:468-75. [CrossRef]

21. Killian G. The origin of choanal polyp. Lancet. 1906; 2:81-2. [CrossRef]

22. Berg O, Carenfelt C, Silfverswärd C, Sobin A. Origin of the choanal polyp. Arch Otolaryngol Head Neck Surg. 1988;114:1270-1. [CrossRef]

23. Min YG, Chung JW, Shin JS, Chi JG. Histologic structure of antrochoanal polyps. Acta Otolaryngol. 1995;115:543-7. [CrossRef]

24. Frosini P, Picarella G, De Campora E. Antrochoanal polyp: analysis of 200 cases. Acta Otorhinolaryngol Ital. 2009;29:21-6.
25. Al-Qudah M. Bilateral antrochoanal polyps: possible pathogenesis. J Craniofac Surg. 2011;22:1116-8. [CrossRef]

26. Knör M, Tziridis K, Agaimy A, Zenk J, Wendler O. Human Papillomavirus (HPV)Prevalence in Nasal and Antrochoanal Polyps and Association with Clinical Data. PLoS One. 2015;10:e0141722. [CrossRef]

27. Yılmaz E, Alatas N, Ucar F, Cora T, Buruk K, Unlu Y. Investigation of Human Papillomavirus (HPV) and Epstein-Barr Virus (EBV) in antrochoanal polyps. Am J Otolaryngol. 2019;40:389-392. [CrossRef]

28. Maldonado M, Martínez A, Alobid I, Mullol J. The antrochoanal polyp. Rhinology. 2004;42:178-82.

29. Raap U, Braunstahl GJ. The role of neurotrophins in the pathophysiology of allergic rhinitis. Curr Opin Allergy Clin Immunol. 2010;10:8-13. [CrossRef]

30. Wu X, Myers AC, Goldstone AC, Togias A, Sanico AM. Localization of nerve growth factor and its receptors in the human nasal mucosa. J Allergy Clin Immunol. 2006;118:428-33. [CrossRef]

31. Noga O, Englmann C, Hanf G, Grützkau A, Seybold J, Kunkel G. The production, storage and release of the neurotrophins nerve growth factor, brain-derived neurotrophic factor and neurotrophin-3 by human peripheral eosinophils in allergics and non-allergics. Clin Exp Allergy. 2003;33:649-54. [CrossRef] 